УДК 33.2964 .338

\title{
ТЕНДЕНЦІї ТА ПЕРСПЕКТИВИ РОЗВИТКУ ЗЕЛЕНОЇ ЕКОНОМІКИ В УКРАЇНІ
}

\section{TRENDS AND PROSPECTS OF GREEN ECONOMY DEVELOPMENT IN UKRAINE}

\author{
Сич Карина Олексіївна \\ магістерка, \\ Поліський національний університет \\ ORCID: https://orcid.org/0000-0002-0013-9315 \\ Бугайчук Віта Віталіївна \\ кандидат економічних наук, доцент, \\ Поліський національний університет \\ ORCID: https://orcid.org/0000-0002-7282-1794 \\ Грабчук Інна Францівна \\ кандидат економічних наук, доцент, \\ Поліський національний університет \\ ORCID: https://orcid.org/0000-0001-5548-6034 \\ Sych Karyna, Bugaychuk Vita, Grabchuk Inna \\ Polissia National University
}

\begin{abstract}
У статті розглянуто поняття «зеленої» економіки, її основні принципи та завдання, а також проаналізовано та обґрунтовано існуючі тенденції та перспективи розвитку цієї галузі в Україні з урахуванням сучасного стану та проблем, що перешкоджають розвитку «зеленої» економіки на даному етапі. Проблеми з нераціональним використанням вичерпних природних ресурсів, варварські методи ведення бізнесу, націлені не на задоволення потреб споживачів і якість продукції, а лише на отримання вигоди, використовуючи в господарській діяльності єнергозатратні технології з високим рівнем накопичення відходів у навколишньому середовищі. Наразі, технологічні, економічні, екологічні та соціальні проблеми бізнесу зумовлюють перегляду цілої системи організації безпечного існування суспільства та забезпечення його добробуту. Таким чином виникнення «зеленої економіки» стало необхідним для суспільства, адже саме такий вид економіки поєднує в собі усі сфрери життєдіяльності. «Зелена економіка» є унікальною економікою, яка перед суспільством несе відповідальність за зростання його добробуту, шляхом раціонального використання можливостей оточуючого світу. Ії̈ особливістю $€$ те, що вона не може існувати автономно та тісно взаємопов'язана з економікою навколишнього середовища, циркулярною, екологічною, феміністською, соціальною та біо-економіками. Вони є взаєдоповнюючими та нероздільними, оскільки кожна з них виконує особливі функції щодо цивілізованого розвитку суспільства. Зелена економіка грунтується на принципах добробуту, справедливості, планетних меж, ефрективності та достатності і належного управління. Такі принципи визначають нові підходи до розвитку економіки окремого суб'єкта господарювання та, загалом, національної економіки. Оцінка розвитку зеленої економіки поєднує показники, які мають враховувати оцінки раціональності використання природних ресурсів, масштаби викидів виробничих токсинів у навколишнє середовище та кількість підприємств економічна діяльність яких пов'язана природоохоронними цілями розвитку суспільства.
\end{abstract}

Ключові слова: «зелена» економіка, сталий розвиток, державна політика, перспективи розвитку, система державного управління.

В статье рассмотрено определение «зеленой» экономики, ее основные принципы и задачи, а также проанализированы и обоснованны существующие тенденции и перспективы развития этой отрасли в Украине с учетом современного состояния и проблем, препятствующих развитию «зеленой» экономики на данном этапе. Проблемы с нерациональным использованием невосполнимых природных ресурсов, варварские методы ведения бизнеса, нацелены не на удовлетворение потребностей потребителей и качество продукции, а только на получение выгоды, используя в хозяйственной деятельности енергозатратные технологии с высоким уровнем накопления отходов в окружающей среде. Сейчас технологические, экономические, экологические и социаль- 
ные проблемы бизнеса обусловливают пересмотра всей системы организации безопасного существования общества и обеспечения его благосостояния. Таким образом возникновение «зеленой экономики» стало необходимым для общества, ведь именно такой вид экономики сочетает в себе все ссеры жизнедеятельности. «Зеленая экономика» является уникальной экономикой, которая перед обществом несет ответственность за рост его благосостояния, путем рационального использования возможностей окружающего мира. Ее особенностью является то, что она не может существовать автономно и тесно взаимосвязана с экономикой окружающей среды, циркулярной, экологической, феминистской, социальной и био-экономиками. Они неразделимы, поскольку каждая из них выполняет особые фрункции по цивилизованного развития общества. Зеленая экономика основывается на принципах благосостояния, справедливости, планетных границ, эффеектиности и достаточности, а также надлежащего управления. Такие принципы определяют новые подходы к развитию экономики отдельного субъекта хозяйствования и, в общем, национальной экономики. Оценка развития зеленой экономики сочетает показатели, которые должны учитывать оценки рациональности использования природных ресурсов, масштабы выбросов производственных токсинов в окружающую среду и количество предприятий экономическая деятельность которых связана природоохранными целями развития общества.

Ключевые слова: «зеленая» экономика, устойчивое развитие, государственная политика, перспективы развития, система государственного управления.

The article considers the concept of "green" economy, its main principles and objectives, as well as analyzes and substantiates the existing trends and prospects of this industry in Ukraine, taking into account the current state of its development and problems hindering the development of "green" economy at this stage. Problems with the irrational use of exhaustible natural resources, barbaric methods of doing business, aimed not at meeting consumer needs and product quality, but only at profit, using energy-intensive technologies with a high level of waste accumulation in the environment. At present, technological, economic, environmental and social problems of business determine the revision of the entire system of organization of the safe existence of society and ensure its well-being. Thus, the emergence of a "green economy" has become necessary for society, because this type of economy combines all spheres of life. The "green economy" is a unique economy that is accountable to society for the growth of its welfare, through the rational use of the opportunities of the surrounding world. Its peculiarity is that it cannot exist autonomously and is closely interconnected with the environmental, circular, ecological, feminist, social and bio-economies. They are complementary and inseparable, as each of them performs special functions in relation to the civilized development of society. The green economy is based on the principles of prosperity, justice, planetary boundaries, efficiency and sufficiency, and good governance. Such principles define new approaches to the development of the economy of an individual business entity and, in general, the national economy. The assessment of the development of the green economy combines indicators that should take into account assessments of the rational use of natural resources, the scale of emissions of industrial toxins into the environment and the number of enterprises whose economic activities are related to environmental development goals.

Keywords: "green" economy, sustainable development, public policy, development prospects, public administration system.

Постановка проблеми. Протягом останніх десятиліть через значні негативні зміни, що відбуваються у природному середовищі, все більшої актуальності набувають питання екології, збереження та захисту довкілля. Особливо важливими стають питання екологізації економіки, адже масштабної шкоди довкіллю завдає саме економічна сфера людської діяльності, яка здійснює свій негативний влив через неправильне та нераціональне використання природних ресурсів, постійне збільшення масштабів виробництва та зростання кількості промислових об'єктів, які не відповідають нормам екологічної безпеки тощо. 3 огляду на таку ситуацію, багато країн у світі впроваджують нові екологічні технології виробництва, удосконалюють системи ефективного використання ресурсів та розвивають так звану «зелену» економіку. Що стосується України, то вона ще тільки наближається до таких необхідних змін та робить перші кроки у цьому напрямі. Тому наразі надзвичайно важливим $€$ дослідження наявного потенціалу, можливостей перспективи та тенденцій розвитку «зеленої» економіки.

Аналіз останніх досліджень та публікацій по темі. На даному етапі питання дослідження «зеленої» економіки в Україні цікавить багатьох вітчизняних дослідників, що підтверджується досить значною кількістю праць, присвячених цій проблемі. Зокрема, над цим питанням працюють такі науковці як Галушкіна Т.П., Гарлицька Д.А., Маковоз О.С., Мамалига В.О., Марченко О.І., Мірошниченко В.В., Потапенко В.Г., Скороход І.С. та багато інших. Проте, не зважаючи на велику кількість досліджень щодо впровадження «зеленої» економіки в Україні, окремі проблеми та перспективи ії розвитку все ще $\epsilon$ недостатньо розглянутими та містять протиріччя, тому вважаємо цю тему й досі актуальною. Варто відзначити, що на законодавчому 
рівні також розглядається концепція «зеленої» економіки, яка представлена низкою нормативно-правових актів, 3-поміж яких Розпорядження Кабінету Міністрів України «Про схвалення Стратегії залучення, використання та моніторингу міжнародної технічної допомоги і співробітництва з міжнародними фрінансовими організаціями на 2013-2016 роки», Закон України «Стратегія сталого розвитку «Україна 2020»» [5]. Однак, на даному етапі в Україні не існує комплексної державної політики щодо впровадження та розвитку «зеленої» економіки, а стратегія сталого розвитку країни має лише декларативний характер, що унеможливлює її практичне виконання.

Постановка завдання. Метою даного дослідження $€$ обґрунтування основних тенденцій та наявних перспектив розвитку «зеленої» економіки в Україні. Для досягнення поставленої мети необхідно вирішити наступні завдання - обґрунтувати поняття «зеленої економіки», узагальнити головні її принципи та завдання, окреслити тенденції перспективного розвитку «зеленої» економіки в Україні.

Виклад основного матеріалу дослідження. Відповідно до визначення, яке подається у Програмі Організації Об'єднаних Націй 3 навколишнього середовища (ЮНЕП), «зелена» економіка - це економіка, що орієнтується на покращення добробуту людства та соціальну рівність, шляхом істотного скорочення ризиків від змін навколишнього середовища і нестачі природних екологічних ресурсів [1].

Сьогодні чимало країн у світі, зокрема Данія, Швеція, Японія, Нова Зеландія, Мексика активно впроваджують дану концепцію, при цьому демонструючи швидкі темпи економічного зростання, високі макроекономічні показники та поліпшення рівня життя населення, що засвідчують високий рівень розвитку їх економік [6, с. 535]. Зважаючи на такі результати, можемо стверджувати, що «зелена» економіка має позитивний вплив не тільки на екологію, наприклад на сповільнення надмірного видобування та використання корисних копалин, перехід до використання відновлюваних джерел енергії, а й на економічний розвиток.

Мета «зеленої» економіки полягає в тому, щоб забезпечити реалізацію співпраці трьох головних напрямів розвитку, а саме соціального благополуччя, економічного зростання та охорони навколишнього середовища. Тобто, «зелена» економіка вимагає налагодженого та есрективного фрункціонування трьох осно- вних фракторів сталого розвитку - соціального, економічного та екологічного. Варто наголосити, що зусилля, які докладаються всіма учасниками для переходу до «зеленої» економіки повинні поєднати потребу в отриманні прибутку в короткостроковій та середньостроковій перспективі, а також визначити довгострокове системне перетворення. Ключовим у забезпеченні ресурсами й гарантуванні соціального захисту та справедливості, які потрібні для фрінансування дій та розвитку потужності, спрямованих на перехід до «зеленої» економіки є економічне зростання.

Серед особливо важливих видів діяльності, що відносяться до «зеленої» економіки виділяють впровадження відновлювальних джерел енергії, енергоесективності будівель, стабільний енергоесрективний транспорт, сільське господарство й вода, а також утилізацію відходів та ефективне використання матеріалів у виробничих процесах [6, с. 536].

Незважаючи на унікальність та загальну мету, напрям «зеленого» розвитку економіки може володіти певними специсрічними рисами у відповідності із людськими, природними та економічними ресурсами різних країн. Так, розвинуті країни можуть скеровувати свої зусилля на підвищення енергоефективності будівництва й транспорту, урбаністичну політику та землекористування. Дослідники виокремлюють досить велику кількість економічних інструментів та ринкових механізмів для переходу на засади «зеленої» економіки. Для прикладу, приватні та державні інвестиції у так зване «зелене виробництво», політика державних закупівель, що стимулює виробництво екологічної продукції, обмін еко-технологіями між країнами, цільова державна підтримка різноманітних досліджень та розробок, які пов'язані зі створенням екологічно чистих технології тощо [8, с. 93].

Разом з тим, слід зазначити, що існує чимало проблем у розвитку та переході до «зеленої» економіки, серед основних проблем науковці виділяють нестачу внутрішніх фрінансових ресурсів, відсутність сприятливих інвестиційних умов, наявність економічних ризиків впровадження енергоощадних та безвідходних технологій, низький рівень екологічної свідомості та ін. [10, с. 17].

Щодо впровадження «зеленої» економіки в Україні, то спостерігається чимало проблем, зокрема, відсутність цілісної державної політики, а також висока енерговитратність виробництва, велика кількість відходів, що головним чином спричинена видобувною про- 
мисловістю, досить високий рівень енергоспоживання, що супроводжується низьким рівнем споживання енергії, яка генерується з відновлюваних джерел, недостатні розміри зелених тарифрів, які стають на заваді появі бажаного ефекту збільшення використання альтернативних джерел енергії, що спричинене недостатньою зацікавленістю населення.

Окрім зазначених вище, виділяють ще й інші не менш важливі проблеми, серед яких: мала частка відходів, які переробляються; повна відсутність або недостатнє фрінансування галузі, яка потребує значних капіталовкладень, особливо на початкових етапах; негативні зміни стану ґрунтового покриву, що має суттєвий вплив на загальний розвиток сільського господарства; застарілість як виробничої, так і соціальної інфрраструктури; технологічна недосконалість значної частини виробництва основних видів продукції, а також недостатня та неефективна «пропагандистська» та інфрормаційна діяльність, спрямована на поширення серед населення ідей концепції «зеленої» економіки [7, с. 83].

Також варто зазначити, що для України на сучасному етапі розвитку характерні й додаткові внутрішні проблеми, які пов'язані із втратою контролю над частиною ії території. За таких непростих умов перед урядом нашої держави постає складне та комплексне завдання, яке полягає у тому, щоб вирішити всі внутрішні проблеми, реалізувати зобов'язання передбачені Угодою $3 \in C$, активно сприяти трансорормації національної економіки та спрямувати розвиток держави стійким шляхом. Для уможливлення вирішення цих завдань, необхідно формувати державну політику розвитку «зеленої» еко- номіки як головного інструмента для досягнення сталого розвитку, який з урахуванням усіх вимог здатен реагувати на внутрішні та зовнішні зміни таким чином, щоб досягти стабільності еколого-економічної ситуації в державі. Але, перш за все, потрібно прийняти єдину стратегію, розробити план та чітко слідувати наміченим маршрутом у розвитку «зеленої» економіки в Україні [2, с. 130].

Незважаючи на численні наявні проблеми, що стають на заваді впровадження та розвитку «зеленої» економіки, в Україні наявні й певні передумови для ії розвитку, які представлені на рисунку 1.

По-перше, це наявність значних запасів чорнозему та сприятливі кліматичні умови, хоча й ресурсозбереження не $\epsilon$ пріоритетним напрямом економічного зростання в нашій державі. Другою передумовою $€$ швидке вичерпання органічного палива та запасів корисних копалин. Третя передумова розвитку «зеленої» економіки полягає у наявній можливості перспективного розвитку вітрової енергетики в Україні шляхом освоєння гірських та степових районів. Ще однією передумовою $€$ наявність широких можливостей та перспектив для розвитку сільського господарства, зокрема органічного землеробства. Адже, для цього в нашій державі $€$ всі необхідні ресурси, а саме: значні за обсягом площі чорноземів, низький рівень використання хімічних добрив та пестицидів, експортний потенціал для країн Західної Європи та доступність робочої сили [6, с. 540].

Зазначимо, що помітним поштовхом для активізації розвитку та запровадження «зеленої» економіки в Україні стало підписання Угоди про Асоціацію з ЄС у 2014 році.

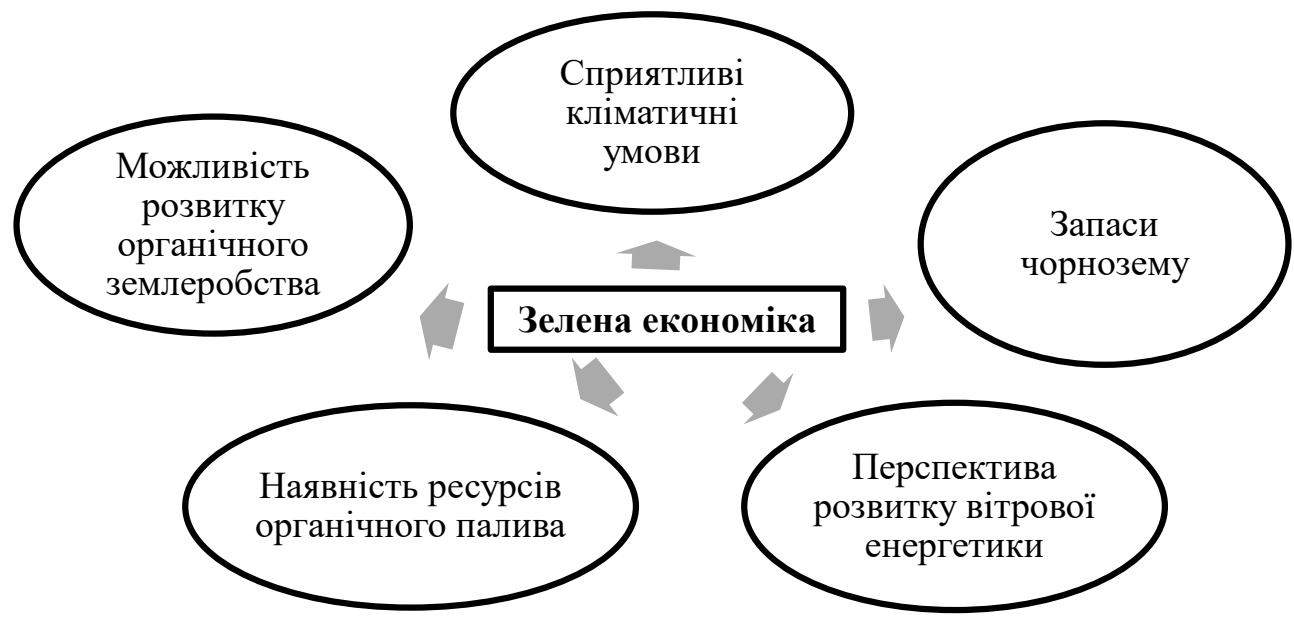

Рис. 1. Передумови розвитку «зеленої» економіки в Україні

Джерело: розроблено авторами на основі даних [6, с. 540] 
Адже, саме її економічна частина передбачає реформування податкової системи задля виконання своїх зобов'язань, гармонізацію законодавства до стандартів $€ C$, розробку стратегії інвестування у розвиток новітніх технологій, що спрямовуються на зменшення шкоди природі, а також розвиток співпраці у сорері захисту довкілля [3, с. 15].

На наш погляд, Україна володіє досить значним потенціалом, який необхідний для впровадження «зеленої» економіки на практиці, але, щоб реалізувати його необхідно враховувати наступні принципи та підходи:

1) підвищувати ефективність економіки шляхом поетапного зменшення використання сировини, води, матеріалів, викопних джерел палива тощо;

2) впроваджувати зелені технології, продукції, послуг, процесів та сприяти ефрективній діяльності зеленого бізнесу й розширенню його частки в структурі економіки;

3) стимулювати створення нових підприємств зеленого бізнесу та перехід діючих підприємств до більш зелених, які повинні забезпечуватися через впровадження відповідних інструментів податкової, цінової, фрінансової та інвестиційної політики [5];

4) дотримуватися ресурсоефективності, енергоефективності та впроваджувати зелені технології, які $€$ пріоритетними напрямами для отримання кредитів та інвестування. Доцільним також $є$ впровадження державної сертифрікації зелених підприємств, послуг, технологій та продукції для надання їм стимулів щодо отримання кредитів та інвестування $[9$, с. 120];

5) здійснювати структурні зрушення у напрямі енергоефективної та низьковуглецевої економіки із заощадливим використанням природних ресурсів, що передбачають комплексний підхід до запровадження «зеленої» промисловості, сектору інорраструктури та екологічних послуг, а також створення екоінноваційних кластерів;

6) здійснювати інформаційні кампанії 3 метою пояснення населенню важливості та необхідності переходу до ресурсозбереження у повсякденному житті, сприяти переробці ресурсів та дотриманню правил раціонального управління відходами.

Окрім дотримання усіх необхідних принципів та правил, втілення моделі «зеленої» економіки також передбачає збільшення ролі держави та державних органів як в економічному, так і в екологічному регулюванні, співпрацю держави та бізнесу, створення сприятливих умов для розвитку бізнесу на базі нових екологічних технологій і стандартів та державну підтримку соціально-екологічно відповідальних підприємств, а також сприяння діяльності некомерційних екологічних об'єднань та організацій, створення необхідних умов для розвитку у населення екологічної культури й популяризацію просвітницьких програм та ініціатив ресурсозбереження [4, с. 42].

Висновки та перспективи подальших досліджень. Отже, можемо зробити висновок, що «зелена» економіка $\epsilon$ складовою частиною сталого розвитку та передбачає гармонійне співіснування економічної, соціальної систем і навколишнього середовища. Що стосується розвитку «зеленої» економіки в Україні, то наразі, попри існування перспектив та значного потенціалу, спостерігається відсутність єдиного підходу та чіткої стратегії щодо розвитку цієї сорери, а також наявність низки інших важливих проблем, що потребують негайного вирішення. 3 поміж яких проблеми використання природних копалин та ресурсів, охорони навколишнього середовища, відсутності фрінансування даного напряму тощо.

Тому, сьогодні варто зупинитися на вирішенні низки наявних проблем, розробити цілісну та ефективну концепцію впровадження та розвитку «зеленої» економіки в Україні, а також розпочати впровадження цієї стратегії на практиці. Адже, тільки збалансоване поєднання екологічних, економічних та соціальних фракторів розвитку нашої держави допоможе їй стати на шлях сталого розвитку та досягти економічного зростання і високого рівня якості життя населення.

\section{СПИСОК ВИКОРИСТАНИХ ДЖЕРЕЛ:}

1. About green economy. United Nations Environment Programme: вебсайт. URL: https://www.unenvironment.org/ explore-topics/green-economy/about-greeneconomy (дата звернення: 29.08.2021).

2. Балуєва О.В., Кумачова А.С. Особливості комплексної державної політики розвитку «зеленої» економіки в Україні в умовах системних змін. Інвестиції: практика та досвід. 2016. № 24. С. 130-135.

3. Гарлицька Д.А. Побудова зеленої економіки - основна складова європейської інтеграції України. Економічна думка. 2017. № 2(27). С. 15-19. 
4. Гура А.О., Гуцан Т.Г. Зелена економіка: сутність, чинники та перспективи розвитку в Україні. Збірник наукових праць Харківського національного педагогічного університету імені Г.С. Сковороди «Економіка». 2017. № 17. С. 42-51.

5. Маковоз О.С. Зелена економіка як запорука сталого розвитку. URL: http://dspace.univd.edu.ua/xmlui/ bitstream/handle/123456789/4372/Zelena\%20ekonomika\%20yak\%20zaporuka\%20staloho\%20rozvytku_ Makovoz_Perederii_2018.pdf?sequence=1\&isAllowed=y (дата звернення: 29.08.2021).

6. Марченко О.І., Мамалига В.О. Зелена економіка: теоретичні аспекти. Східна Європа: економіка бізнес та управління. 2019. № 6(23). С. 535-541.

7. Мірошниченко В.В., Тьорло В.О. Проблеми становлення «зеленої» економіки в Україні. Наукові записки НаУКМА. Економічні науки. 2018. № 1(3). С. 83-88.

8. Основні засади впровадження моделі «зеленої» економіки в Україні : навч. посіб. / Т.П. Галушкіна, Л.А. Мусіна, В.Г. Потапенко та ін.; за наук. ред. Т.П. Галушкіної. Київ : Інститут екологічного управління та збалансованого природокористування, 2017. 154 с.

9. Потапенко В.Г. Стратегічні пріоритети безпечного розвитку України на засадах «зеленої економіки» : монографрія / за наук. ред. д.е.н., проф. Є.В. Хлобистова. Київ : НІСД, 2012. 360 с.

10. Скороход І.С., Горбач Л.М. Розвиток зеленої економіки в країнах Європейського Союзу. Вчені записки Таврійського національного університету імені В.І. Вернадського. Серія : Економіка і управління. 2019. Випуск 30(69). № 2. С. 17-21.

\section{REFERENCES:}

1. About green economy. United Nations Environment Programme. Avaliable at: https://www.unenvironment.org/ explore-topics/green-economy/about-greeneconomy (accessed 29 August 2021).

2. Baluieva O.V., Kumachova A.S. (2016) Osoblyvosti kompleksnoi derzhavnoi polityky rozvytku "zelenoi" ekonomiky $v$ Ukraini $v$ umovakh systemnykh zmin [Features of a comprehensive state policy for the development of a "green" economy in Ukraine in the context of systemic change]. Investytsii: praktyka ta dosvid, no. 24, pp. 130-135.

3. Harlytska D.A. (2017) Pobudova zelenoi ekonomiky - osnovna skladova yevropeiskoi intehratsii Ukrainy [Building a green economy is a key component of Ukraine's European integration]. Ekonomichna dumka, no. 2(27), pp. 15-19.

4. Hura A.O., Hutsan T.H. (2017) Zelena ekonomika: sutnist, chynnyky ta perspektyvy rozvytku v Ukraini [Green economy: essence, factors and prospects of development in Ukraine]. Zbirnyk naukovykh prats Kharkivskoho natsionalnoho pedahohichnoho universytetu imeni H.S. Skovorody "Ekonomika", no. 17, pp. 42-51.

5. Makovoz O.S. (2018) Zelena ekonomika yak zaporuka staloho rozvytku [Green economy as a guarantee of sustainable development]. Avaliable at: http://dspace.univd.edu.ua/xmlui/bitstream/handle/123456789/4372/ Zelena\%20ekonomika\%20yak\%20zaporuka\%20staloho\%20rozvytku_Makovoz_Perederii_2018.pdf?sequence= 1\&isAllowed=y (accessed 29 August 2021).

6. Marchenko O.I., Mamalyha V.O. (2019) Zelena ekonomika: teoretychni aspekty [Green economy: theoretical aspects]. Skhidna Yevropa: ekonomika biznes ta upravlinnia, no. 6(23), pp. 535-541.

7. Miroshnychenko V.V., Torlo V.O. (2018) Problemy stanovlennia "zelenoi" ekonomiky v Ukraini [Problems of formation of "green" economy in Ukraine]. Naukovi zapysky NaUKMA. Ekonomichni nauky, no. 1(3), pp. 83-88.

8. Halushkina T.P., Musina L.A., Potapenko V.H. ta in. (2017) Osnovni zasady vprovadzhennia modeli "zelenoi" ekonomiky v Ukraini [The main principles of implementing the model of "green" economy in Ukraine]. Kyiv: Instytut ekolohichnoho upravlinnia ta zbalansovanoho pryrodokorystuvannia.

9. Potapenko V.H. (2012) Stratehichni priorytety bezpechnoho rozvytku Ukrainy na zasadakh "zelenoi ekonomiky" [Strategic priorities for safe development of Ukraine on the basis of "green economy"]. Kyiv: NISD.

10. Skorokhod I.S., Horbach, L.M. (2019) Rozvytok zelenoi ekonomiky v krainakh Yevropeiskoho Soiuzu [Development of the green economy in the countries of the European Union]. Vcheni zapysky Tavriiskoho natsionalnoho universytetu imeni V.I. Vernadskoho. Seriia: Ekonomika i upravlinnia, vol. 30(69), no. 2, pp. 17-21. 